\title{
Desain Aplikasi Efkids untuk Menstimulasi Sikap Kewirausahaan pada Anak Usia Dini
}

\author{
Riska Aprilianti ${ }^{\circledR}$, Gaharani Saraswati², Wulanda Aditya Azis ${ }^{3}$ \\ Pendidikan Guru Pendidikan Anak Usia Dini, Sekolah Tinggi Keguruan dan Ilmu \\ Pendidikan Sebelas April Sumedang $(1,2,3)$ \\ DOI: $10.31004 /$ obsesi.v6i1.834
}

\begin{abstract}
Abstrak
Penelitian ini dilatarbelakangi pentingnya media yang dapat mengenalkan pendidikan kewirausahaan pada anak. Tujuannya untuk menghasilkan media pembelajaran yang layak dan efektif dalam menstimulasi sikap kewirausahaan pada anak. Metode yang digunakan adalah Riset and Development (R\&D) dengan pedekatan Brog and Gall. Pengumpulan data menggunakan teknik observasi, judgment expert, tes, dan dokumentasi. Tempat dilaksanakan di TK NP dengan subjek pada 2 orang ahli dan sebanyak 16 orang anak. Analisis mengguankan jugment expect dan uji Independent Samples Test dengan statistik SPSS. Hasil dalam penelitian ini berupa aplikasi EFKIDS yang dapat dipergunakan guru dan anak dengan bantuan Adobe Flash Player. Adapun hasil dari penilaian ahli menunjukan layak dipergunakan oleh pengguna yaitu guru dan anak. Hasil uji efektivitas menunjukan lebih efektif dibandingkan media sebelumnya yaitu buku cerita dengan hasil uji independent samples test menunjukkan nilai pada baris equal variances assumed kolom Sig. sebesar 0.000 yang artinya terdapat perbedaan sikap kewirausahaan yang sangat signifikan.
\end{abstract}

Kata Kunci: sikap kewirausahaan; anak usia dini; aplikasi efkids

\section{Abstract}

This research is motivated by the importance of the media which can introduce an entrepreneurship education to the children. The goal of this research is for producing an appropriate and an effective learning media in stimulating entrepreneurial attitudes in children. The method that was used is Research and Development (R\&D) with the Brog and Gall approachment. Collecting data using observation techniques, expert judgment, tests, and documentation. The research was held in NP Kindergarten with 2 experts and 16 children as the subjects. The analysis of this research was using judgement expectation and independent samples test with SPSS statistics. The results of this study is the EFKIDS application which can be used by the teacher and the children by using Adobe Flash Player. The result of the expert's judgement indicate that the application is feasible for the user (teacher and children). The result of the effectiveness test shows that this media is more effective than the previous one media, namely story books, with the results of the independent samples test showing the value on the equal variances assumed column Sig. of 0.000 , which means that there are very significant differences in entrepreneurial attitudes.

Keyword: entrepreneurship attitude; early childhood; efkids application

Copyright (c) 2021 Riska Aprilianti, Gaharani Saraswati, Wulanda Aditya Azis

$\triangle$ Corresponding author :

Email Address : riskaaprilianti094@gmail.com (Sumedang, Indonesia)

Received 23 October 2020, Accepted 20 December 2020, Published 30 Maret 2021 


\section{PENDAHULUAN}

Saat ini jumlah kesempatan kerja yang tidak sebanding dengan jumlah lulusan yang mencari pekerjaan menyebabkan bertambahnya jumah pengangguran. Apalagi di masa pandemi seperti ini, jumlah pengangguran semakin meningkat. Menurut (Uswatun, 2019) pengangguran masih menjadi permasalahan bagi negara Indonesia. Jika melihat data dari Badan Pusat Statistika (BPS) jumlah angkatan kerja pada Agustus Tahun 2020 sebanyak 138,22 juta orang, hal tersbeut naik sebesar 2,36 juta orang dibandingkan Agustus Tahun 2019, sehingga tingkat pengangguran terbuka sebesar 7,07\% meningkat 1,84\% dibandingkan Agustus 2019. Melihat bertambahanya pengangguran saat ini tentunya perlu adanya suatu upaya untuk mengurangi pengangguran. Salah satu upaya yang dapat dilakukan adalah dengan cara memiliki keterampilan dalam berwirausaha. Dengan berwirausaha minimal seseorang dapat menciptakan lapangan pekerjaan untuk dirinya sendiri dan jika usaha semakin maju, maka dapat membuka lapangan pekerjaan bagi orang lain pula. Keterampilan dalam berwirausaha dapat membantu seseorang untuk memiliki jiwa mandiri, kreatif, dan berani mengambil resiko. Seperti yang diketahui bahwa kewirausahaan itu sebagai semangat, perilaku, dan kemampuan seseorang dalam menangani usaha yang mengarah pada upaya mencari, menciptakan, menerapkan cara kerja, teknologi, dan produk baru dengan meningkatkan efesiensi dan pelayanan guna memperoleh keuntungan (Susilaningsih, 2015). Melihat pentingnya kewirausahaan tersebut, maka perlu dikenalkan pada anak sejak usia dini.

Pendidikan kewirausahaan pada anak usia dini merupakan sebuah usaha dalam menumbuhkan dan mengembangkan sikap serta karakter yang telah ada pada diri anak (Fithriyana, 2016). Adapun nilai-nilai kewirausahaan yang dikembangkan dalam dunia pendidikan di antaranya mandiri, kreatif, berani mengambil resiko, berorientasi pada tindakan, kepemimpinan, kerja keras, jujur, disiplin, inovatif, tanggung jawab, kerjasama, pantang menyerah, rasa ingin tahu, dan komunikasi (Wibowo, 2011). Untuk menstimulasi nilai-nilai tersebut tentunya tidak mudah, karena jika melihat perkembangan anak usia dini berada pada tahapan praoprasional dimana mereka belajar secara simbol, gambar, dan bermain. Untuk menjebatani kebutuhan tersebut maka kegiatan pembelajaran membutuhkan sebuah media pembelajaran yang menarik dan mudah diingat oleh anak.

Media pembelajaran sendiri dapat digunakan sebagai alat komunikasi yang tidak akan pernah lepas dalam dunia pendidikan. Selain itu media tidak hanya sebagai alat komunikasi saja, tetapi menjadi alat yang dapat membantu dan mempermudah penyampaian suatu pesan. Sehingga media memiliki peranan yang sangat penting dalam proses kegiatan pembelajaran khususnya dapat meringankan guru saat penyampaian materi pembelajaran. Menurut (Zaini \& Dewi, 2017) media pembelajaran memiliki manfaat lain yaitu dapat menstimulasi aspekaspek perkembangan pada anak dan bagi anak media dijadikan sebagai alat untuk bermain. Dengan adanya media, penyampaian materi mengenai kewirausahaan diharapkan mudah dipahami oleh anak. Namun pada kenyataanya walaupun media itu dapat membantu menyampaikan sebuah pesan, tidak semua media dapat dioptimalkan oleh guru. Keterbatasan guru dengan media-media yang ada menjadikan kendala tersendiri dalam menyampaikan kewiraushaan pada anak. Dampak dari keterbatasan tersebut dimana nilainilai kewiraushaan tidak tersampaikan pada anak. Seperti yang diungkapkan oleh (Yohanna \& Maya, 2019) Ketika sekolah mengenalkan pendidikan kewirausahaan sejak dini maka hasilnya akan lebih baik, sayangnya tidak semua sekolah menerapkan pendidikan kewirausahaan dengan baik. Jika dilihat dari kebutuhan lapangan mengapa tidak semua sekolah menerapkan pendidikan kewiraushaan yaitu karna terbatasnya media pembelajaran.

Seperti hasil observasi dari salah satu sekolah di Taman Kanak-kanak (TK) Kabupaten Sumedang, menunjukkan bahwa guru-guru memiliki keterbatasan media yang mengenalkan kewirausahaan pada anak. Guru-guru masih menggunakan bentuk media pembelajaran klasikal dengan bantuan berupa buku cerita, gambar, dan boneka. Penggunaan media tersebut berdampak pada profesi pedagang tidak tersampaikan pada anak. Contohnya pada 
saat guru menjelaskan pedagang sayur dengan media boneka, anak tidak memahami deskripsi pedagang sayuran itu seperti apa. Sedangkan anak harus memahami secara utuh deskripsi pedagang sayur itu dari segi visualisasi, apa yang dijualnya, dan sikap kewirausahaan yang dimiliki oleh pedagang sayur tersebut. Untuk bisa menumbuhkan nilainilai tersebut maka tugas dari guru adalah menyediakan sarana dalam membimbing dan membentuk sikap kewirausahan pada anak (Prasetyaningsih, 2016).

Tentunya ada beberapa penelitian terdahulu yang telah menghasilkan sebuah metode dan media yang dapat menstimulasi nilai-nilai kewiraushaan pada anak. Seperti kegiatan market day yang dapat membangun dan menumbuhkan jiwa kewiraushaan pada anak usia dini melalui kegiatan langsung menjadi seorang penjual dan pembeli (Uswatun, 2019). Selain itu ada yang menerapkan nilai-nilai kewiraushaan pada kegiatan sehari-sehari, seperti menyiram tanaman, memberi makan ikan, bekebun, dan panes sayur (Saugi et al., 2020). Dari kedua hasil tersebut terlihat dalam menstimulasi nilai-nilai kewiraushaan dilaksankan kegiatan secara langsung belajar pada sumbernya, seperti anak diajak untuk melakukan kegiatan-kegiatan menanam makanan dan menjadi pedagang. Namun kegiatan tersebut tidak dapat dilaksankaan di saat pademi Covid 19 saat ini sehingga guru-guru membutuhkan sebuah inovasi media dalam dunia pendidikan. Inovasi media tersebut dapat menumbuhkan minat dan imajinasi anak terhadap sosok seorang pedagang. Tentunya pada kegiatan market day tidak bisa dilaksankan. Sehingga harapan dari kebutuhan guru adalah media yang dapat diakses dimanapun anak berada. Sehingga media ini dapat mempermudah anak dalam memahami tema atau materi pembelajaran dengan mudah. Melihat kebutuhan tersebut maka media yang perlu kembangkan untuk melengkapi media sebelumnya adalah teknologi visual animasi. Tentunya media kewiraushaan yang berbasis visual animasi ini belum ada yang menciptkan sehingga ini menjadi peluang untuk dapat dikembangkan.

Melihat teknologi saat ini semakin berkembang dan berdampak pada setiap lini kehidupan tak terkecuali dalam dunia pendidikan. Kehadiran teknologi memudahkaan bagi dunia pendidikan khusunya dalam proses kegiatan pembelajaran. Teknologi dalam dunia pendidikan dijadikan sebagai media yang dapat membantu guru saat proses kegiatan pembelajaran, baik membantu bersifat admintratif maupun proses pembelajaran. Dalam kegiatan pembelajaran, teknologi membantu guru dalam proses penyampaian pesan yang menarik dan interaktif sehingga dapat meningkatkan minat anak untuk mengikuti kegiatan pembelajaran (Nisa', 2020). Sebagai usaha untuk memanfatakan teknologi tersebut, maka sebuat aplikasi game dikembangkan. Tentunya game yang mestimulasi sikap-sikap kewirausahan pada anak usia dini saat ini belum banyak dibuat. Salah satu penelitian terdahulu yang menguatkan penelitian ini adalah game based learning sebagai metode penunjang pembelajaran kewiraushaan (Hidayat, 2018).

Game merupakan sesuatu yang dapat dimainkan oleh pengguna dan memiliki aturan untuk mencapai tujuan. Game sendiri akan membuat pengguna yang sedang bermain menjadi senang. Memanfaatkan game dalam proses kegiatan pembelajaran masih jarang digunakan. Oleh karena itu perlu adanya pengembangan terhadap game agar dapat dimanfaatkan sebagai media kegiatan pembelajaran yang menyenangkan. Game edukasi yang dapat dikembangkan sebagai wahana anak untuk belajar dengan cara yang menyenangkan. Game yang memiliki nilai edukatif adalah game yang memberikan pengalaman belajar bagi pengguna dan bersifat mendidik melaui sajian-sajian yang terdapat pada game tersebut (Eka Jayanti et al., 2018). Salahsatu bentuk game yang akan dibuat tetap mengutamakan prinsip tersebut. Game yang berhasil dibuat dalam penelitian ini adalah EFKIDS yang artinya Entrepreneurship for Kids (kewiraushaan untuk anak). EFKIDS merupakan sebuah program perangkat lunak yang dikembangkan dalam desktop komputer atau laptop. Aplikasi EFKIDS ini berupa audio visual animasi yang menarik di dalamnya terdapat cerita, lagu, dan permainan dengan lima jenis pedagang. Lima jenis pedagang tersebut diantaranya pedagang sayuran, buah, ikan, es krim, dan kue. Indikator yang dikembangkan dalam aplikasi game 
EFKIDS sendiri diantaranya sikap berani, mandiri, kreatif, inovatif, jujur dan bertanggung jawab.

Game EFKIDS ini memiliki kelebihan yang tidak dimiliki oleh kegiatan seperti market day. Adapun klebihannya dapat dimainkan dimanapun anak berada khususnya saat pandemi saat ini diamana guru memiliki batasan dalam proses kegiatan pemeblajaran. Kegiatan dalam game EFKIDS ini diperkenakan pada tokoh pedagang secara visual, kegiatan yang dilakukan pedagang melalui lagu dan cerita visual, dan permainan-permainan yang dapat menumbuhkan sikap kewiraushaan pada anak. Selain itu game EFKIDS dapat menstimulasi enam aspek perkembangan pada anak. Tentunya dengan sajuan materi dalam game tersebut menjadi nilai yang tidak miliki pada kegiatan atau media yang sudah ada. Melihat keunggulan dalam game EFKIDS tersebut maka pembuatan media EFKIDS ini perlu dibuat guna memenuhi kebutuhan guru. Penelitian ini menghasilkan tiga rumusan yaitu bagaimana membuat aplikasi EFKIDS, bagimana kelayakan aplikasi EFKIDS, dan bagaimana keefektivitas aplikasi tersebut terhadap sikap kewirausahaan anak usia 5-6 tahun. Adapun tujuannya adalah untuk menghasilkan media yang layak dan efektif digunakan oleh guru dalam mestimulasi sikap-sikap kewiraushaan pada anak usia dini.

\section{METODOLOGI}

Berdasarkan studi pendahuluan dimana dibutuhan pembuatan media yang dapat menstimulasi sikap kewraushaan pada anak maka metode yang digunakan dengan Research and Development (R\&D). Research and Development sendiri merupakan sebuah metode penelitian dengan tujuan menghasilkan dan menguji keefektivan sebuah media atau produkproduk pendidikan (Sugiyono, 2007). Motode Research and Development ini menggunakan pendekatan dari Brog and Gall dengan sembilan tahapan yaitu (1) studi pendahuluan, (2) perencanaan penelitian, (3) pengembangan produk, (4) uji kelayakan oleh ahli, (5) perbaikan, (6) uji coba lapangan terbatas, (7) perbaikan, (8) uji loba lebih luas, dan (9) desiminasi produk. Adapun alur dalam penelitian ini dapat dilihat dilihat pada gambar 1.

Melihat ahlur dalam penelitian ini akan fokus pada proses pengembangan media, uji keayakan, dan uji lebih luas. Adapun tahapannya : (1) untuk studi pendahuluan akan mengkaji teori dan hali-hali penelitian terdahulu yang berkaitan dengan penelitian kewiraushaan. (2) merumuskan tujuan dari penelitian ini yang berikatan dengan konsep dari media yang akan dikembangkan. (3) proses dari pengembangan media dimana memilih media yang tepat dengan guru dan anak usia dini. (4) uji kelayakan yang akan dilakukan oleh dua orang ahli dari media dan materi. (5) proses perbaikan dari ahli sebelum diuji cobakan, (6) uji coba terbatas yang dilakukan pada satu orang guru dan 4 anak dengan tujuan untuk meminimalisir kekurangan. (7) perbaikan atas temuan dilapangan setalah di uji coba secara terbatas. (8) uji coba lebih luas untuk mengetahu kefektivan dari media yang teah dibuat terhadap sikap kewiraushaan pada anak. (9) desiminasi media. Proses pengembangan aplikasi EFKIDS ini dilakukan selama 8 bulan yang dilaksankan di sekolah TK NP Sumedang. Karakeristik anak yang menjadi subjek peneltian ini yaitu Kelompok B dengan usia rentan 56 tahun. Jumlah sampel yang digunakan dalam penelitian ini yaitu 2 orang ahli dan 16 anak. Data diambali dengan menggunakan lembar observasi, angket, wawancara, dan tes. Data yang terkumpul akan di analisis dengan: (1) uji kelayakan menggunakan jugment expect dengan penilaian skala sikap (Sukarjo, 2005). (2) uji efektivitas menggunakan pre eksperiment one grup pre test post test melalui uji Independent Samples Test dengan statistik SPSS. 


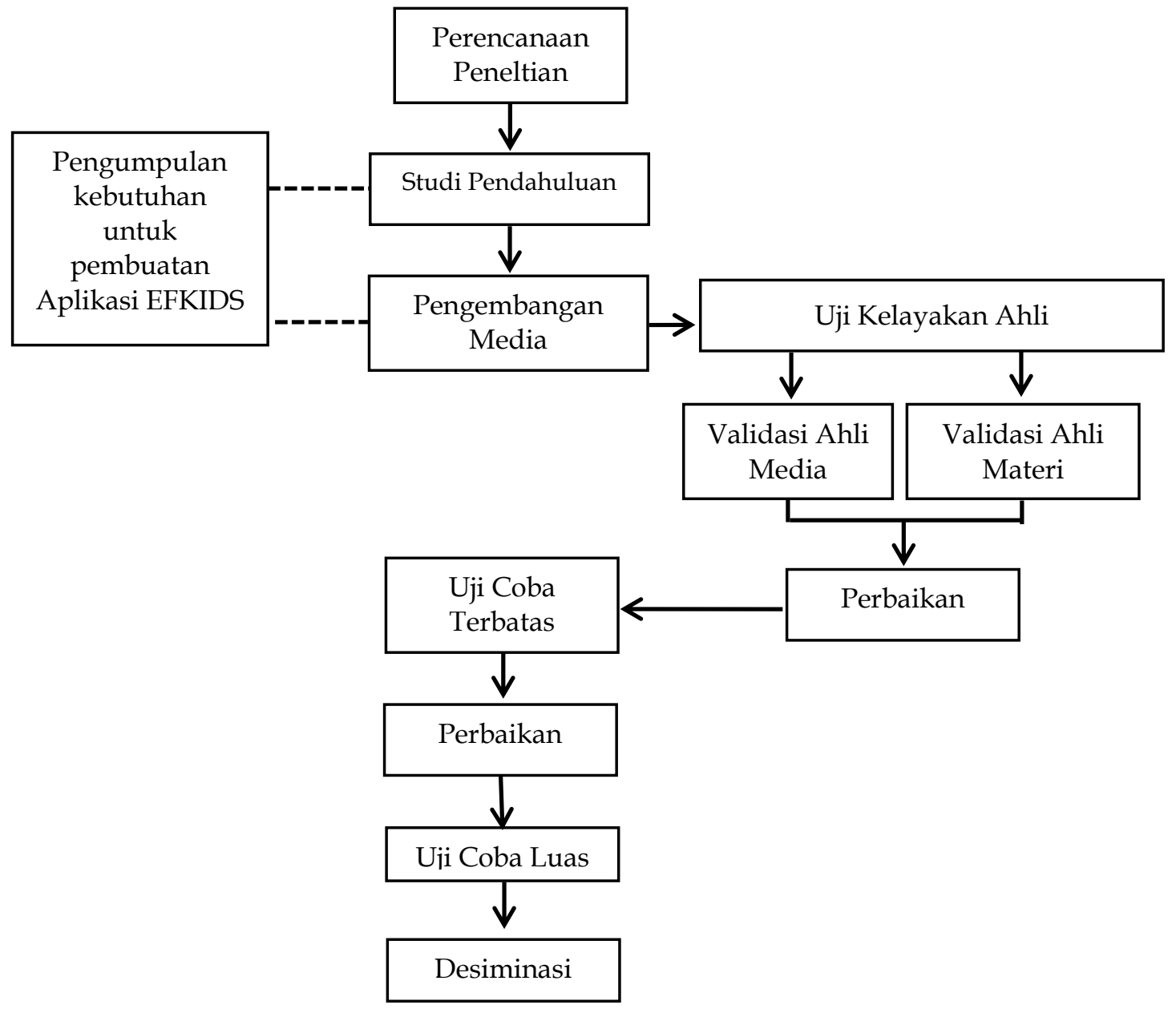

Gambar 1. Alur penenelitian

\section{HASIL PENELITIAN DAN PEMBAHASAN}

\section{Hasil Pengembangan}

Langkah pertama ditahapan ini adalah membuat sebuah media yang sesuai dengan kebutuhan lapangan, dimana media memudahkan guru menyampaikan materi dalam pembelajaran. Selain itu sekolah membutuhkan media yang terinteregrasi dengan teknologi serta terdapat visual animasi di dalamnya. Setelah melihat kebutuhan tersebut maka peneliti membuat sebuah aplikasi EFKIDS yang dikemas dengan game edukatif. Adapun hasil dari pembuatan media tersebut dapat di liahat pada Gambar 2.

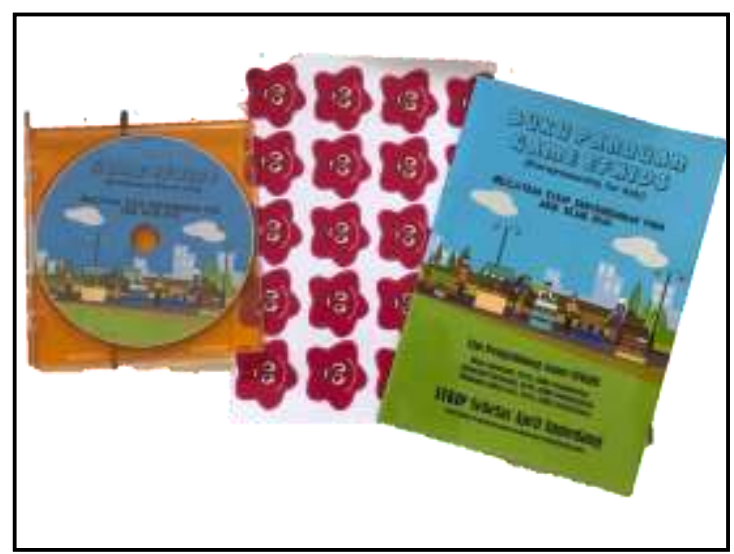

Gambar 2. Aplikasi EFKIDS 
Aplikasi EFKIDS pada Gambar 2 terdiri dari satu buah Compact Disc Recordabel (CD-R), satu buah buku panduan, dan satu lembar stiker reward. Dalam CD-R tersebut terdapat sebuah game yang dapat di instal pada setiap personal computer (PC) baik dengan tipe windows maupun macOs. Sedangkan untuk buku panduan dibuat untuk memudahkan guru saat akan menggunakan aplikasi EFKIDS. Buku panduan EFKIDS sendiri di lengkapi dengan instrumen penilaian mengenai sikap kewirausahaan pada anak. Sebagai bahan masukan dari pengguna (guru) buku panduan ini dilengkapi dengan stiker reward yang dapat ditempel pada baju anak sebagai bentuk memberikan motivasi dan penghargaan (Fadlilah, 2020). Aplikasi EFKIDS sendiri tidak hanya dilengkapi dengan buku panduan saja namun terdapat lagu jingle "aku seorang pedagang" yang akan menjadikan EFKIDS sebagai media pembelajaran yang menarik bagi anak.

Apliaksi EFKIDS ini terdapat tiga kegiatan yaitu: (1) kegiatan bernyanyi, (2) becerita, dan (3) permainan. Ketiga kegiatan tersebut disesuiakan dengan standar permainan edukasi untuk anak dimana game harus memiliki standar intruksi yang jelas, standar kemampuan kognitif, standar kemampuan psikomotorik, standar kemampuan mengingat, dan standar memberi penilaian (Delima et al., 2015). Standar-standar tersebut telah ada dalam game EFKIDS dimana dalam game ini terdapat lima tema pedagang yang akan digunakan dalam setiap cerita. Lima pedagang tersebut terdiri dari pedagang sayuran, buah, ikan, es krim, dan kue. Adapun tampilan pertama dimana anak akan diajak untuk bernyanyi bersama dapat lihat pada Gambar 3.

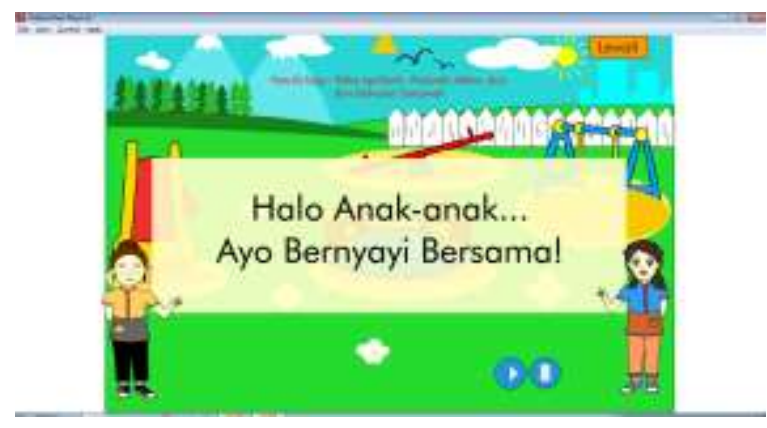

Gambar 3. Tampilan Kegiatan Bernyanyi pada Aplikasi EFKIDS

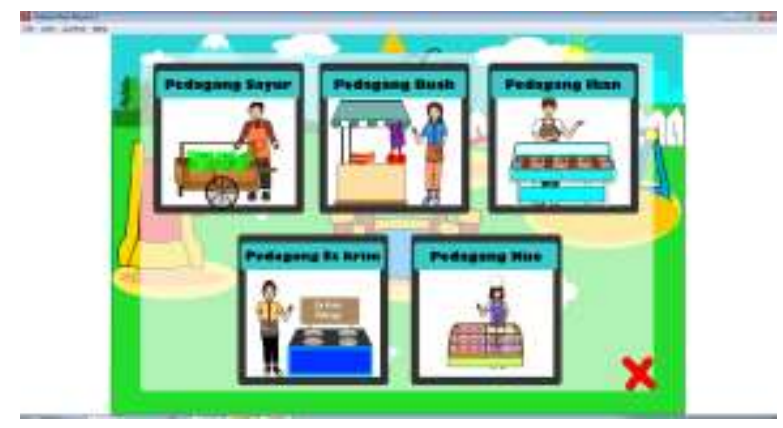

Gambar 4. Tampilan Lima Pedagang pada Aplikasi EFKIDS

Tampilan pertama pada Gambar 3 dimana anak akan diajak bernyanyi dengan judul lagu "aku seorang pedagang". Tujuan dari bernyanyi untuk mengenalkan sikap kewirausahaan melalui pesan yang ada dalam lagu tersebut. Adapun sikap-sikap yang terdapat dalam lagu tersebut diantaranya berani, bertanggung jawab, dan jujur. Setelah kegiatan bernyanyi, kemudian anak akan masuk pada kegiatan mendengarkan cerita yang didalamnya terdapat lima karakter pedagang. Dalam game EFKIDS musik menjadi bagian yang tidak terpisahkan. Manfaat yang berada dalam musik dapat meningkatkan kemampuan kognitif, sosial emosional, dan motork. Sehingga musik memiliki dampak yang sangat besar bagi peningkatan kualitis pendidikan yang tidak terpisahkan (Kihoro, 2016). Lima karakter pedagang dalam aplikasi EFKIDS dapat dilihat pada Gambar 4.

Tampilan kedua akan muncul yaitu kelima pedagang yang diantaranya pedagang sayur, buah, ikan, es krim, dan kue. Pemilihan jenis-jenis pedagang tersebut disesuiakan dengan pedagang yang sering anak lihat. Dalam pembuatannya tema-tema tersebut tdibuat dengan tujuan untuk melatih dan memecahkan masalah, selain itu memerikan pilihan kepada pengguna untuk memilih cerita yang ingin dimainkan (V. W. Febriani et al., 2017). Untuk kegiatan bercerita dapat dilihat pada Gambar 5. 


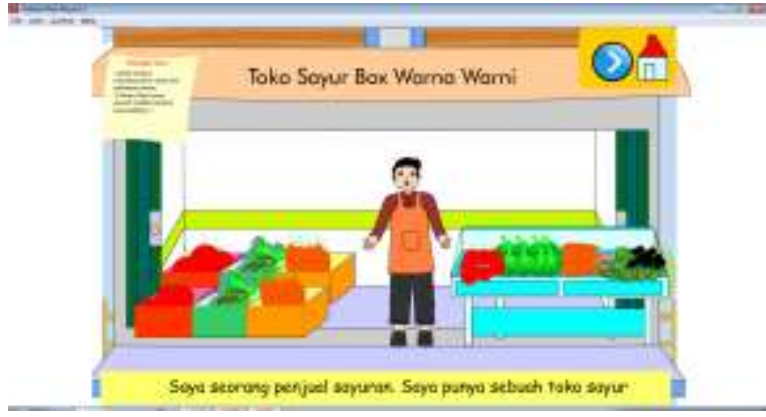

Gambar 5. Menu Lima Pedagang

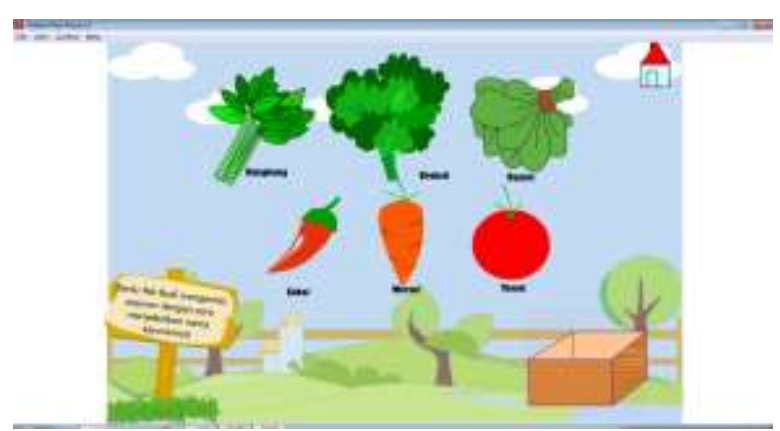

Gambar 6. Permainan Menyebutkan dan Mengelompokan Sayuran

Kegiatan bercerita dibuat pada setiap tema pedagang dengan tujuan untuk menyampaikan pesan dari seorang pedagang serta melatih kemampuan menyimak anak. Diharapkan dengan kegiatan mendengarkan cerita dapat menyampaikan sikap-sikap yang dimiliki oleh setiap pedagang. Namun jauh lebih luas bercerita sendiri memiliki banyak manfaat yaitu memberikan informasi, menyerap pesan dari cerita, mengembangkan imajinasi, dan melatih daya ingat (Darmila et al., 2018). Kegiatan ketiga adalah permainan yang dapat dilihat pada Gambar 6. Gambar 6 merupakan perwakilan dari kelima pedagang. Kegiatan permainan tersebut telah disesuaikan dengan standar perkembangan anak sehingga tidak hanya mengenalkan sikap kewirausahaan pada anak saja. Dari hasil pengembangan tersebut telah dilakukan uji kelayakan oleh ahli materi dan media.

\section{Uji Kelayakan}

Penilaian validasi ahli dilakukan dengan memberikan angket kepada dua orang ahli. Ahli pertama adalah seorang ahli media yang memahami mengenai pembuatan aplikasi komputer sedangkan ahli kedua adalah ahli materi yang menguasai dunia pendidikan anak usia dini. Tujuan dari kegiatan ini adalah untuk menghasilkan sebuah media yang layak dan dapat digunakan oleh pengguna. Kegiatan ini dilakukan selama tiga kali hingga aplikasi EFKIDS siap dan layak untuk di uji coba pada anak.

Penilaian pertama dilakukan oleh ahli media. Adapun indikator yang dinilai oleh ahli tersebut diantaranya: (1) uji keseimbangan (blance testing), (2) uji kegunaan (usability testing), dan uji memainkan (play testing) (Levy \& Novak, 2010). Uji keseimbangan sendiri terdiri dari lima sub indikator, yaitu: (a) dimana sebuah tantangan dalam game EFKIDS dibuat secara konsisten, (b) tidak ada kesalahan sistem software yang tiba-tiba terhenti, (c) pemain tidak terjebak dengan tidak ada jalan keluar, (d) pemain dapat membuat keputusan, dan (e) pemain dapat menyesuaikan dengan tingkat kesulitan. Berdasarkan hasil kelima sub indikaor tersebut mendaptkan skor rata-rata 4,4. Jika merujuk pada penilaian skala sikap nilai tersebut maka keseimbangan (blance testing) berada di kategori "baik".

Penilaian indikator berikutnya adalah uji kegunaan. Adapun hasilnya menunjukan kriteria baik pada indikator pengujian kegunaan (usability testing). Adapun sub indikatornya diantaranya (a) pemain mudah saat memainkan game, (b) pemain mendapat umpan balik, dan (c) tampilan pada game sesuai serta tidak membosankan. Dari hasil ketiga sub indikator tersebut mendapat rata-rata 4,18, dimana hasil tersebut jika merujuk pada penilaian skala sikap nilai tersebut maka pengujian kegunaan (usability testing) berada di kategori "baik".

Penilaian yang ke tiga uji memainkan (game play testing) EFKIDS. Sub indikator dimana game EFKIDS terdiri dari : (a) dapat membuat pemain merasa terhibur atau senang, (b) mampu menumbuhakan emosional pemain, dan (c) dapat meningkatkan ketertarikan pemain pada audio visual game EFKIDS. Adapun hasil penilaian dari ahli memperoleh skor rata-rata 3,88. Jika merujuk pada penilaian skala sikap maka hasil uji memainkan (play testing) berada di kategori "baik". Untuk melihat secara visualisasi hasil dari jugment expect ahli media dapat dilihat pada Gambar 7. 
Penilaian kedua dilakukan oleh ahli materi dalam bidang pendidikan anak usia dini. Kegiatan validasi oleh ahli media dilakukan dengan tujuan untuk menyempurnakan aplikasi game EFKIDS agar sesuai dengan tahapan perkembangan anak usia dini. Indikator penilaian materi ini adalah kesesuaian pembelajaran dan kesesuaian materi. Adapun hasil penilaian pada indikator kesesuaian pembelajaran mendapat nilai rata-rata 4,25. Adapun penunjang dalam mencapai kriteria tersebut dikarenakan telah mencapai sub indikator diantaranya: (a) kesesuaian dengan tujuan pembelajaran, (b) kesesuaian dengan kurikulum, (b) kesesuaian dengan pendidikan kewirausahaan untuk AUD, (c) ketepatan sebagai media pembelajaran, (d) memiliki interaktivitas, (e) memiliki nilai motivasi, (f) kontekstual, dan (h) memiliki kualitas sebagai media pembelajaran. Jika melihat pada skala sikap hasil tersebut berada pada kriteria "sangat baik".

Sedangkan untuk penilaian indikator kedua mendapatkan hasil dengan rata-rata 3,75. Hasil tersebut didaptkan dari sub indikator : (a) kesesuian materi, (b) kelengakpan media efkids (buku panduan), (c) kesesuaian cerita dengan usia anak, (d) kemudahan digunakan oleh pengguna, (e) mudah dipahami oleh anak 5-6 tahun, (f) ketepatan alat evaluasi. Jika melihat pada skala sikap hasil tersebut berada pada kriteria "baik". Jika dianalisa hasil tersebut bahwa game efkids secara materi telah sesuai denga tujuan dari game itu sendiri yang memiliki edukasi. Menurut kajian ilmiah bahwa game dan play itu berbeda dimana game untuk kepentingan pendidikan, sedangkan play berfungsi memebrikan kesenangan kepada pemain (Ifenthaler et al dalam Hidayat, 2018). Adapun data hasil ahli materi tersebut dapat tergambarkan pada gambar 7 dan 8 . Melihat hasil kedua ahli media dan materi maka aplikasi EFKIDS ini layak dan dapat diuji keefektivannya pada anak.

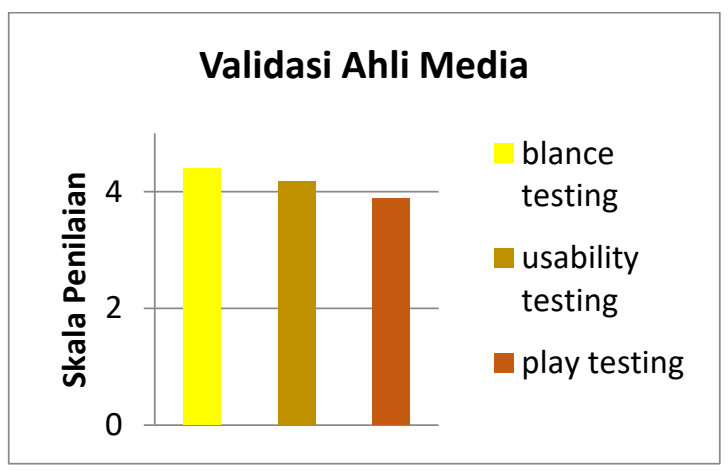

Gambar 7. Grafik Penilaian Ahli Media

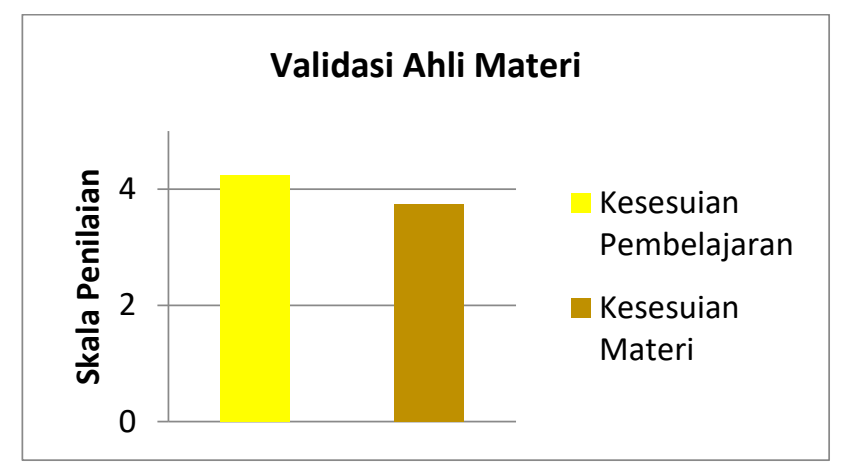

Gambar 8. Grafik Penilaian Ahli Materi

Setelah melakukan kegiatan pretest, treatment, dan posttest maka langkah selanjutnya adalah mengkonversi penilaian yang diadaptasi dari hasil tersebut. Data penelitian pretest dan posttest penelitian datap dilihat pada Tabel 1.

Dari data keseluruhan menunjukkan adanya perbedaan bahwa sikap kewirausahaan anak menggunakan media cerita selama tujuh kali pertemuan menghasilkan nilai sebesar 328, sedangkan menggunakan aplikasi EFKIDS mendapatkan nilai sebesar 394 dari enam belas anak yang menjadi sampel penelitian. Hal ini menunjukkan adanya peningkatan sikap kewirausahaan anak melalui aplikasi EFKIDS. Berdasarkan hasil uji normalitas, hasil penelitian ini menghasilkan data yang dapat dilihat pada Tabel 2.

Berdasarkan hasil uji normalitas pada Tebel 2 menggunakan kolmogorov-Smirnov pada data pre-test menghasilkan signifikansi sebesar 0.200, sedangkan untuk post-test menunjukkan signifikansi sebesar 0.095. Menggunakan analisis Shapiro Wilk menghasilkan signifikansi sebesar 0.450 pada data pretest, sedangkan data posttest menunjukkan signifikansi sebesar 0.106 . 
Desain Aplikasi Efkids untuk Menstimulasi Sikap Kewirausahaan pada Anak Usia Dini DOI: 10.31004/obsesi.v6i1.834

Tabel 1. Data Penilaian Pretest dan Psostest

\begin{tabular}{ccc}
\hline No Sampel & Metode Cerita & Metode EFKIDS \\
\hline 1 & 19 & 26 \\
2 & 17 & 28 \\
3 & 21 & 26 \\
4 & 18 & 23 \\
5 & 19 & 21 \\
6 & 19 & 23 \\
7 & 22 & 28 \\
8 & 24 & 24 \\
9 & 28 & 28 \\
10 & 16 & 20 \\
11 & 22 & 25 \\
12 & 20 & 26 \\
13 & 22 & 26 \\
14 & 22 & 24 \\
15 & 16 & 20 \\
16 & 23 & 26 \\
Jumlah & 328 & 394 \\
\hline
\end{tabular}

Tabel 2. Uji Normalitas

\begin{tabular}{llccccccc}
\hline & \multicolumn{3}{c}{ Tests of Normality } \\
& Eksperimen & \multicolumn{3}{c}{$\begin{array}{c}\text { Kolmogorov- } \\
\text { Smirnova } \\
\end{array}$} & & \multicolumn{4}{c}{ Shapiro-Wilk } \\
& & Stati & & & Stati \\
& stic & df & Sig. & stic & df & Sig. \\
\hline Sikap kewirausahaan & Pre-Test & .130 & 16 & $.200^{*}$ & .947 & 16 & .450 \\
& Post-Test & .198 & 16 & .095 & .908 & 16 & .106 \\
\hline
\end{tabular}

*. This is a lower bound of the true significance.

a. Lilliefors Significance Correction

Dalam penelitian ini digunakan uji normalitas menggunakan Shapiro Wilk dikarenakan sampel yang digunakan sangat kecil jumlahnya, sehingga uji normalitas Kolmogorov Smirnov hasil uji signifikansinya boleh tidak digunakan. Kedua hasil signifikansi baik pretest dan posttest menunjukkan signifikansi $>0.05$ sehingga data sikap enterpreneurship pada anak TK X berdistribusi normal dan dapat diuji menggunakan statistik parametrik. Hasil uji homogenitas dalam penelitian ini menunjukkan hasil yang dapat dilihat pada Tabel 3.

Tabel 3. Uji Homogenitas

\begin{tabular}{lllr}
\hline & & $\begin{array}{l}\text { Levene's Test for } \\
\text { Equality of Vaces }\end{array}$ \\
\hline Sikap Kewirausahaan & $\begin{array}{l}\text { Equal variances assumed } \\
\text { Equal variances not assumed }\end{array}$ & .322 & Sig. \\
\hline
\end{tabular}

Berdasarkan Tabel 3 menunjukkan bahwa berdasarkan uji Levene's Test menunjukkan nilai $\mathrm{F}$ pada bagian equal variances assumed sebesar 0.322 dan signifikansi 0.575 sehingga data ini bersifat homogen. Pada hasil uji normalitas data dikatakan berdistribusi normal dan pada hasil uji homogenitas menghasilkan data bersifat homogen, maka dalam uji hipotesis digunakan analisis statistik parametrik. Berdasarkan pernyataan tersebut, maka baris yang 
diperhatikan untuk penyampaian hasil adalah baris equal variances assumed. Hasil uji hipotesis dalam penelitian ini menunjukkan hasil pada Tabel 4.

Tabel 4. Uji Hipotesis

\begin{tabular}{|c|c|c|c|c|c|c|c|c|}
\hline \multicolumn{9}{|c|}{ Independent Samples Test } \\
\hline \multirow{5}{*}{$\begin{array}{l}\text { Sikap } \\
\text { Kewirausahaan p }\end{array}$} & & \multicolumn{7}{|c|}{ t-test for Equality of Means } \\
\hline & & & & Sig. (2- & Mean & Std. Error & $\begin{array}{r}\text { 95\% Conf } \\
\text { Interval } \\
\text { Differe }\end{array}$ & $\begin{array}{l}\text { dence } \\
\text { f the } \\
\text { nce }\end{array}$ \\
\hline & & $\mathrm{t}$ & $\mathrm{df}$ & tailed) & Difference & Difference & Lower & Upper \\
\hline & $\begin{array}{l}\text { Equal } \\
\text { variances } \\
\text { assumed }\end{array}$ & -3.996 & 30 & .000 & -4.125 & 1.032 & -6.233 & -2.017 \\
\hline & $\begin{array}{l}\text { Equal } \\
\text { variances } \\
\text { not } \\
\text { assumed }\end{array}$ & -3.996 & 29.128 & .000 & -4.125 & 1.032 & -6.236 & -2.014 \\
\hline
\end{tabular}

Berdasarkan Tabel 4 menunjukkan bahwa berdasarkan uji Independent Samples Test menunjukkan nilai pada baris equal variances assumed kolom Sig. (2-tailed) menunjukkan signifikansi sebesar 0.000 yang berarti terdapat perbedaan sikap kewirausahaan pada anak yang sangat kuat atau sangat signifikan setelah diberikan media EFKIDS.

Dari hasil uji keefektivan dapat disimpulkan bahwa aplikasi EFKIDS lebih efektif dalam menstimilasi sikap-sikap kewirausahaan pada anak. Media ini dibuat berdasarkan kebutuhan stakeholder yang menginginkan media berbentuk visual animasi. Kelebihan dari media EFKIDS ini adalah dapat membantu guru mempermudah kegiatan pembelajaran khususnya pada saat tema profesi pedagang. Selain itu media EFKIDS ini juga membuat anak merasa senang selama mendengarkan cerita dan bermain game. Walaupun media ini berbentuk game akan tetapi tetap dapat dikendalikan oleh guru atau orang tua saat anak bermain. Pemilihan game didalam aplikasi EFKIDS sendiri dikarenakan game memiliki keunggulan dibandingkan dengan pembelajaran konvensional, dimana dalam game edukatif membantu anak untuk memiliki daya ingat yang panjang (Vitianingsih, 2016). Selain itu Game mengajarkan mengenai keterampilan literasi, berhitung (kognitif), koordinasi mata tangan (motorik), dan komunikasi. Game edukasi yang mengenalkan sikap kewirausahaan pada anak belum ada dalam pendidikan anak usia dini dan media tersebut dijadikan salah satu pilihan bagi guru. Dengan itu pengembangan game edukatif perlu diciptakan untuk memudahkan guru dalam mengenalkan sikap kewirausahaan pada anak (Clark, 2006). Sehingga dari bergamai macam dampak positif tersebut maka game dapat diimpelemntasikan serta dapat mendukung proses kegiatan pembelajaran. Tentunya jika dibandingakan dengan dua penelitian terdahulu namun aplikasi EFKIDS ini masih memiliki keunggulan khusunya disaat pandemi Covid 19 yang dimana kegiatan pemebelajaran tidak bisa dilaksankan secara tatap muka.

Market day sendiri merupakan sebuah motode pembelajaran berbasih proyek dimana anak dan guru akan terlibat secara langsung dengan dalam menyiapkan jualannya, selain itu jika orang tua yang berjualan anak akan terlibat juga pada proses melayani pembeli (Uswatun, 2019). Tentunya dalam penelitian tersebut memiliki kelebihan dimana anak belajar langsung dengan sumbernya dimana inti dari kewirausahaan sendiri adalah menjalankan proses sebuah usaha. Akan tetapi ada kekurangan dalam penelitian tersebut dimana guru harus menyiapkan segala bentuk bahan-bahan yang dipelrukan dalam kegiatan market day, selain itu guru harus menyeting tempat yang ada tentunya membutuhkan waktu. Berbeda dengan aplikasi EFKIDS sendiri, dimana aplikasi ini mudah damainkan dalam waktu yang relatif singkat. Guru hanya menyiapkan sebuah laptop dan kemudian game dapat dimainkan oleh guru dan anak. Adapun kegiatan dalam permainan tersebut yaitu menyabutkan jenis 
sayuran, buah, mencocokan, berhitung 1-20, mewarnai gambar, dan berkreasi membuat es krim serta kue. Dari kegiatan-kegiatan tersebut setelah di uji cobakan pada anak dapat meningkatkan semangat anak saat kegiatan, mudah mengenal macam-macam pedagang dan mengetahui bagaimana aktivitas pedagang tersebut melaui isi cerita.

Sedangkan penelitian yang lainnya hapir sama yaitu mengenai metode proyek dalam menanamkan nilai-nilai kewiraushaan pada anak. Kegiatan dari metode proyek ini diamna anak akan membuat makanan, memasak, membuat pakaian, dan menanam, hasilnya berdampak pada nilai-nilai kewiraushaan pada anak (Syifauzakia, 2016). Kegatan tersebut sama dengan media budidaya diamana anak diajak secara langsung menjadi seorang petani yang menanam tanaman, melalui kegiatan tersbeut dapat menumbukan karakter seorang pengusaha (Fithriyana, 2016). Ketuamaan dari kedua penelitian tersebut adalah bagaimana anak menjadi tokoh seorang wirausaha secara langsung melalui kegiatan produksi karya baik berupa maknan, sayuran, atau baju. Dari penelitian tersebut menghasilkan sebuah gagasan pada aplikasi EFKIDS untuk tetap mengenalkan tokoh pedagang pada anak namun secara visual. Sehingga anak masih tetap bisa merasakan bagaimana menjadi seorang pedagang. Kelebihan lainnya dari game EFKIDS ini adalah dalam kegiatan bercerita. Game yang dirancang sesuai tujuan pembelajaran akan membangung konsep dan pemahaman anak dan salah satu hasil penelitian bahwa game edukatif berbasis aplikasi android dapat memfasilitasi ketrampilan membaca anak (A. S. Febriani et al., 2020). Diharapkan dengan adanya EFKIDS ini menjadikan media pilihan oleh guru di Indoenisa saat mengenalkan profesi pedagang. Dengan anak mengenal pedagang dan sikap-sikap yang dimilikinya diharpkan akan memberikan dorongan dan motivasi dimasa depat dengan melahirkan manusia yang memiliki jiwa kewirausahaan.

\section{SIMPULAN}

Aplikasi EFKIDS lebih efektif dalam menstimulasi sikap-sikap kewirausahaan pada anak. Hal ini didorong oleh kemampuan orang tua dan guru dalam memandu anak dalam memainkan game. Adanya buku panduan memudahkan pengguna dalam memahami alur dan maksud yang diharapkan dari penelitian ini. Selain itu, pemberian reward oleh guru berupa stiker reward menambah antusiasme anak. Aplikasi EFKIDS cukup disenangi oleh anak dikarenakan di dalamnya terdapat tiga kegiatan di antaranya: bernyanyi, bercerita, dan permainan mendengarkan cerita dan bermain game, sehingga kegiatan bermain tidak monoton. Tema-tema yang disajikan dalam aplikasi ini juga cukup beragam yaitu pedagang sayur, buah, ikan, es krim, dan kue. Hal ini dapat menambah wawasan anak dalam mengenal beragam prosefi wirausaha.

\section{UCAPAN TERIMA KASIH}

Puji dan Syukur kehadirat Allah SWT yang telah memberikan rahmatNya sehingga penulis bisa menyelesaikan kegiatan penelitian ini. Penulis ucapkan terimkasih kepada Kemenristek BRIN yang telah membiayai penelitian ini dan terimkasih kepada STKIP Sebelas April Sumedang melalui UPT Penelitian STKIP Sebelas April yang telah memberikan dukungan dan fasilitas selama penelitian. TK Negeri Pembina Sumedang yang telah mendukung serta memfasilitasi kegiatan penelitian ini dan Tim Editor Jurnal Obsesi yang telah memberikan kesempatan, kritik, saran, dan rekomendasi sehingga artikel ini menjadi lebih baik.

\section{DAFTAR PUSTAKA}

Borg, W. R. and M. D. Gall. 1989. Educational Research: An Introduction. Fifth Edition. New York and London: Longman.

Badan Pusat Statistika (2020). Tingkat Pengangguran Terbuka (TPT) Sebesar 7,07\%. Retrieved 30 Desember 2020, from Badan Pusat Statistik (BPS). 
Clark, D. (2006). Games and Learning Games and Learning. Caspian Learning.

Darmila, L., Hasibuan, H. B., \& Nunzairina. (2018). Perkembangan Kokakata Anak Usia. Jurnal Raudhah, 06(01), 1-8. https://doi.org/10.30829/raudhah.v6i1.276

Delima, R., Arianti, N. K., \& Pramudyawardani, B. (2015). Identifikasi Kebutuhan Pengguna Untuk Aplikasi Permainan Edukasi Bagi Anak Usia 4 sampai 6 Tahun. Jurnal Teknik Informatika Dan Sistem Informasi, 1(1).

Eka Jayanti, W., Eva, M., \& Fahriza, N. (2018). Game Edukasi "Kids Learning" Sebagai Media Pembelajaran Dasar untuk Anak Usia Dini Berbasis Android. KOPERTIP : Jurnal Ilmiah Manajemen Informatika dan Komputer, 2(2), 98-104. https:// doi.org/10.32485/kopertip.v2i2.56

Fadlilah, A. N. (2020). Strategi Menghidupkan Motivasi Belajar Anak Usia Dini Selama Pandemi COVID-19 melalui Publikasi. Jurnal Obsesi : Jurnal Pendidikan Anak Usia Dini, 5(1), 373. https://doi.org/10.31004/obsesi.v5i1.548

Febriani, A. S., Mulyana, E. H., \& Rahman, T. (2020). Pengembangan Educative Game Berbasis Aplikasi Android untuk Memfasilitasi Keterampilan Membaca Anak Usia 5-6 Tahun. Jurnal Paud Agapedia, 2(2), 187-196. https://doi.org/10.17509/jpa.v2i2.24544

Febriani, V. W., Chandrawati, B., \& Widiantoro, D. (2017). Making Education Game to Choose Healthy Snacks for Children. SISFORMA, 3(1), 26. https:// doi.org/10.24167/sisforma.v3i1.621

Fithriyana, R. (2016). Peningkatan Kewirausahaan melalui Pembelajaran dengan Menggunakan Media Budidaya pada Anak Usia Dini di TK Taqifa Bangkinang Kota Tahun 2016. Jurnal PAUD Tambusai, 2, 26-35.

Hidayat, R. (2018). Game-Based Learning: Academic Games sebagai Metode Penunjang Pembelajaran Kewirausahaan. Buletin Psikologi, 26(2), 71. https:// doi.org/10.22146/buletinpsikologi.30988

Illene Nabila Putri, Euis Kurniati, R. (2020). Pandangan Guru Tentang Penanaman Nilai Nilai Kewirausahaan Untuk Anak Usia Dini. Edukasi, 17(229), 11-18.

Kihoro, M. F. (2016). Ignore it at your own Peril: Using Music to Enhance the Quality of Education. International Journal of Academic Research in Progressive Education and Development, 5(2), 77-85. https://doi.org/10.6007/IJARPED/v5-i2/2094

Levy, L., \& Novak, J. (2010). Game development essentials : game QA \& testing. USA: Delmar.

Nisa', L. (2020). Pemanfaatan Teknologi Dalam Pendidikan Anak Usia Dini. ThufuLA: Jurnal Inovasi Pendidikan Guru Raudhatul Athfal, 8(1), 001. https://doi.org/10.21043/thufula.v8i1.6283

Prasetyaningsih, A. (2016). Membentuk Jiwa Kewirausahaan pada Anak Usia Dini melalui Kegiatan "Market Day." SELING: Jurnal Program Studi ..., 2, 88-102.

Saugi, W., Sundari, I., \& Agustiah, A. (2020). Penanaman Karakter Kewirausahaan di TK Alam Al-Azhar Kutai Kertanegara. As-Sibyan: Jurnal Pendidikan Anak Usia Dini, 5(1), 9. https://doi.org/10.32678/as-sibyan.v5i1.2379

Sugiyono. (2007). Metode Penelitian Kuantitatif Kualitatif dan R\&D. Alfabeta.

Sukarjo, dkk. (2005). Desain pembelajaran: evaluasi pembelajaran handout perkuliahan: Program Pascasarjana Universitas Negeri Yogyakarta.

Susilaningsih, S. (2015). Pendidikan Kewirausahaan di Perguruan Tinggi: Pentingkah untuk Semua Profesi? Jurnal Economia, 11(1). https:// doi.org/10.21831/economia.v11i1.7748

Syifauzakia. (2016). Penanaman Nilai-Nilai Kewirausahaan pada Anak Usia Dini Melalui Metode Proyek (Penelitian Tindakan Kelas pada Anak Kelas B2 RA Miftahul Falah di Kecamatan Cileunyi Kabupaten Bandung). Jurnal Tunas Siliwangi, 2(1), 92-113.

Uswatun, H. (2019). Upaya Menumbuhkan Jiwa Entrepreneurship Melalui Kegiatan Market Day Bagi Anak Usia Dini. Jurnal Pengabdian Masyarakat, 1(1), 8-19. https://doi.org/10.35473/ijec.v1i1.135

Vitianingsih, A. V. (2016). Game Edukasi Sebagai Media Pembelajaran Pendidikan Anak Usia Dini. Jurnal INFORM, 1(1), 1-8. https:// doi.org/10.37438/jimp.v1i1.7

Wibowo, A. (2011). Pendidikan kewirausahaan (Konsep dan startegi. Pustaka Pelajar.

Yohanna, L., \& Maya, S. (2019). The Emergence of Character and Entrepreneurial Spirit Since Childhood. Proceedings of the 1st International Conference on Economics, Business, Entrepreneurship, and Finance (ICEBEF 2018), 65(Icebef 2018), 679-682. https:// doi.org/10.2991/icebef-18.2019.145

Zaini, H., \& Dewi, K. (2017). Pentingnya Media Pembelajaran untuk Anak Usia Dini. Raudhatul Athfal: Jurnal Pendidikan Islam Anak Usia Dini, 1(1), 81-96. https://doi.org/10.19109/ra.v1i1.1489 